\title{
A Comparison of a Short Versus Long Postal Questionnaire on Childbirth-related Incontinence: a Randomised Controlled Trial to Evaluate Response Rates.
}

\section{Sara S Webb ( $\nabla$ s.s.webb@bham.ac.uk)}

Institute of Applied Health Research, College of Medical and Dental Sciences, University of Birmingham, Edgbaston, B15 2TT UK https://orcid.org/0000-0002-4924-3017

\section{E Jones}

University of Birmingham Institute of Applied Health Research

\section{J Bishop}

University of Birmingham, BCTU

\section{MacArthur}

University of Birmingham, Institute of Applied Health Sciences, College of Medical and Dental Sciences

\section{Research article}

Keywords: Long and short Postal Questionnaire, Urinary Incontinence, Pelvic Floor, Postnatal

Posted Date: October 12th, 2020

DOI: https://doi.org/10.21203/rs.3.rs-89366/v1

License: (c) (1) This work is licensed under a Creative Commons Attribution 4.0 International License.

Read Full License 


\section{Abstract}

\section{Background}

A future cluster randomised controlled trial (CRCT) to test an intervention to prevent postpartum urinary incontinence will use a postal questionnaire from women to obtain outcomes. This is part of a programme of work that has the overall aim of reducing the proportion of women with urinary incontinence after birth. One part of the programme was a methodology trial to compare a longer questionnaire, which includes all outcomes, with a shorter questionnaire, which includes only the most important outcomes, in order to maximise women's response to these sensitive questions.

\section{Methods}

A multicentre, stratified by community midwife team, with balanced randomisation [1:1] controlled, parallel group trial was undertaken including women under the care of 15 community midwife teams in three West Midlands NHS trusts who had given birth 10-12 weeks previously. Women under 16 years and women without a live baby on hospital discharge were excluded. Eligible women under the care of each midwife team were individually randomised in a 1:1 ratio to receive either a long or short questionnaire. Both questionnaires included questions on urinary and bowel incontinence and about advice and information on pelvic floor muscle exercise (PFME) and their PFME practice. The long questionnaire included additional questions about women's confidence in undertaking pelvic floor muscle exercise (PFME) and their general health. For women randomised to the short questionnaire, the additional questions were only sent to women who returned the first questionnaire. The primary outcome of this trial was the response rate for completion of the urinary incontinence (UI) questions. Secondary outcomes were urinary incontinence (using ICIQ-UI SF), bowel incontinence (using RFIS), women's performance of PFME and their confidence in this (using PFMSES) and their general health (using SF12).

\section{Results}

777 women were sent a questionnaire and $241(31 \%)$ returned a completed questionnaire. There was no difference in the completion rate of the UI questions according to questionnaire length: $30.5 \%(119 / 387)$ of the women in the long questionnaire arm answered the $\mathrm{UI}$ questions compared with $31.5 \%(123 / 390)$ of those in the short questionnaire arm.

\section{Conclusions}

This study has used high quality trial methods and shown that response rates to the postpartum UI questions were comparable from either a longer or shorter questionnaire.

\section{Trial Registration}

ISRCTN Registry: ISRCTN99859966. Date registered: 10/09/2018: http://www.isrctn.com/ISRCTN99859966 


\section{Background}

Postal questionnaires are frequently used to collect data for research despite commonly high rates of non-response, which both introduces bias and reduces the effective sample size (1). There has been an increasing decline in response rates to surveys over the past 30 years (2). Suggestions for this decline include time pressures, increasing number of surveys in circulation and concerns over the use of personal data (3). This decline has been particularly the case in questionnaire studies relating to maternity care (4, 5). A Cochrane review last updated in 2009 on the methods of postal and electronic questionnaires to increase response rates found various effective strategies to increase response rate to postal questionnaires (6). These included using shorter questionnaires, monetary incentives, pre-notification, follow-up contact, personalisation and first-class mailing. Although more recent research has supported the use of monetary incentives and follow-up contact (7-9), the use of shorter questionnaires and personalisation remains equivocal (8-11).

The Antenatal Preventative Pelvic Floor Exercises and Localisation (APPEAL) programme is a five-year NIHR funded programme of research aimed at reducing the proportion of women who have urinary incontinence ( $\mathrm{UI})$ after birth by increasing the number of women correctly doing PFME during pregnancy. The final part of the research will be a feasibility and pilot cluster randomised controlled trial to test the effectiveness of an intervention to prevent postpartum urinary incontinence, developed during earlier parts of the programme. The above Cochrane review also found that the likelihood of response was reduced when the questionnaires included questions on a sensitive topic. Consequently, because of the sensitivity of questions and necessity to maximise response rate in our cluster trial, a methodology trial was undertaken first. The aim of this study was to assess whether a longer questionnaire, which included all outcomes, or a shorter questionnaire, which included only the most important outcomes, would result in a higher response rate to sensitive questions on urinary incontinence.

\section{Methods}

\section{Objectives}

The primary objective was to assess whether a long or short questionnaire would give a higher response rate to the urinary incontinence questions, which would comprise the primary outcome in the subsequent cluster RCT (12). A second objective was to assess the prevalence of urinary stress incontinence to be used in the subsequent cluster trial.

Study design

This study was a multicentre, stratified by community midwife team, with balanced randomisation [1:1] controlled, open-label, parallel group trial. This study adheres to CONSORT guidelines and a completed CONSORT checklist as provided as an additional file (Additional file 1).

Setting and sample 
The study took place in three NHS trusts with maternity services in the West Midlands. Women who gave birth whilst under the care of any of the 15 community midwifery teams during the study period and who met the eligibility criteria were included. Women who were not eligible were those under 16 years of age, or who did not have a live baby on hospital discharge.

\section{Procedure}

The first 54 consecutive women to give birth during July 2018 in each of these 15 teams (see later for sample size) were informed by their community midwife at their first postnatal home visit that they would receive a postal questionnaire 10-12 after birth. The midwife briefly explained what the questionnaire was about and that its return was voluntary.

The questionnaires comprised a number of validated measures to assess urinary incontinence (ICIQ-UI SF), bowel incontinence (RFIS), efficacy of PFME (PFMSES) and general health (SF-12) as well as some questions about advice and information that the women may have received on PFME in their pregnancy and their own practice of PFME (13-15).

The long questionnaire comprised two double-sided pages and included all of the measures noted above. It also included tick boxes for the women to give consent to access maternity hospital records, request for study results and agreement to be contacted in the future in case of for further research (Additional file 2).

The short questionnaire comprised one double-sided page and did not include PFMSES and SF12(Additional File 3). For women who returned this questionnaire a second short questionnaire which included PFMSES and SF-12 was then sent (Additional file 4).

Randomisation was provided by a confidentially stored computer generated programme at the Birmingham Clinical Trials Unit (BCTU). Participants were randomised at the level of the individual in a 1:1 ratio to either the long or the short questionnaire. The randomisation procedure was stratified by community midwife team to account for potential variation in response rates between the midwife teams in the different socio-demographic areas.

Based on their allocation, the women were sent either the long or short questionnaire by the local Trust research midwives 10-12 weeks after they had given birth, accompanied by a cover letter explaining the study, a $£ 10$ voucher, and stamped return envelope.

The Trust research midwives maintained a log to record the date the initial questionnaire was posted and the date the questionnaires were returned. A reminder letter and questionnaires were sent to women if they had not responded within two weeks of initial questionnaire. Women allocated to the short questionnaire trial arm were only sent the second part of the questionnaire if they returned their initial questionnaire. No further questionnaires were sent to women who did not respond following the reminder letter. 
Sample size

An original sample size of 810 women with an anticipated response rate between $30 \%-60 \%$ would allow the return of between 240 and 480 questionnaires. With a sample size of 810, with 400 allocated to each of two arms, at $80 \%$ power and $5 \%$ significance, the study would be able to detect a $10 \%$ absolute change in the percentage response rate.

\section{Data Analysis}

Urinary incontinence was assessed using the ICIQ-UI SF questionnaire, which asks four questions about different aspects of urinary symptoms. A secondary outcome was the rate of urinary incontinence to be used to power subsequent study sample size. Therefore women were dichotomised into two groups with 'absence' or 'presence' of urinary incontinence. 'Absence' was a response of 'Never', 'None' or score '0' to all of the urinary questions and 'presence' was a response of anything other than 'Never', 'None' or score ' 0 ' to any of the four urinary questions. Rates are reported as frequencies and proportions. Analysis was performed using SAS v9.4 and R v3.6.2. The datasets used and/or analysed during the current study are available from the corresponding author on reasonable request.

\section{Ethics}

Permission was obtained from the Proportionate Review Sub-committee of the London - Brighton \& Sussex Research Ethics Committee (18/LO/0934). This study was funded by NIHR Programme Grant for Applied Research (RP-PG-0514-20002).

\section{Results}

A total of 777 women were randomised and posted either a long or short questionnaire (Figure 1) with an overall response rate of $31.3 \%$ (243/777). The total number of questionnaires sent was less than the planned 810 because two of the small midwife teams had not reached 54 eligible births by the end of the study sample month. Response rates for long and short were consistent across teams. There was no difference found in the response rate either overall or to the UI questions according to questionnaire length. In the long compared with the short questionnaire arm 30.5\% (119/387) of the women responded overall relative to $31.8 \%$ (124/390) (OR 0.95, 95\% Cl 0.70-1.29) and 30.5\% (119/387) answered the UI questions relative to $31.5 \%$ (123/390) (OR 0.96, 95\% Cl 0.71-1.31). Of the 124 women in the short questionnaire arm who responded, only 31 (25\%) completed and returned the second part (part B) of the questionnaire.

Table 1 shows the baseline labour and neonatal characteristics of all women who returned a questionnaire and compares those who returned a long questionnaire to those who returned the short Part A questionnaire. All baseline characteristics were similar between the two groups of women. 
Table 1: Baseline characteristics of all participants - long questionnaire vs short questionnaire Part A 


\begin{tabular}{|c|c|c|c|}
\hline Birth Baseline Characteristic & $\begin{array}{l}\text { Long } \\
(\mathrm{N}=119)\end{array}$ & $\begin{array}{l}\text { Short Part A } \\
(\mathrm{N}=124)\end{array}$ & $\begin{array}{l}\text { Total } \\
(\mathrm{N}=243)\end{array}$ \\
\hline \multicolumn{4}{|l|}{ Labour Onset } \\
\hline Spontaneous onset of labour & $55(46.2 \%)$ & $61(49.2 \%)$ & $116(47.7 \%)$ \\
\hline Induced & $26(21.8 \%)$ & $22(17.7 \%)$ & $48(19.8 \%)$ \\
\hline Not Applicable - Elective C-Section & $14(11.8 \%)$ & $12(9.7 \%)$ & $26(10.7 \%)$ \\
\hline Not Known & $0(0 \%)$ & $0(0 \%)$ & $0(0 \%)$ \\
\hline Missing & $24(20.2 \%)$ & $29(23.4 \%)$ & $53(21.8 \%)$ \\
\hline \multicolumn{4}{|l|}{ Mode of Birth } \\
\hline Spontaneous vaginal & $63(52.9 \%)$ & $65(52.4 \%)$ & $128(52.7 \%)$ \\
\hline Instrumental & $13(10.9 \%)$ & $14(11.3 \%)$ & $27(11.1 \%)$ \\
\hline Caesarean section & $21(17.6 \%)$ & $20(16.1 \%)$ & $41(16.9 \%)$ \\
\hline Missing & $22(18.5 \%)$ & $25(20.2 \%)$ & 47 (19.3\%) \\
\hline \multicolumn{4}{|l|}{ Analgesia } \\
\hline Yes & $26(21.8 \%)$ & $28(22.6 \%)$ & $54(22.2 \%)$ \\
\hline No & $52(43.7 \%)$ & $48(38.7 \%)$ & $100(41.2 \%)$ \\
\hline Missing & $41(34.5 \%)$ & $48(38.7 \%)$ & $89(36.6 \%)$ \\
\hline \multicolumn{4}{|l|}{ Perineum } \\
\hline Intact perineum & $31(26.1 \%)$ & $28(22.6 \%)$ & $59(24.3 \%)$ \\
\hline Labial tear & $0(0 \%)$ & $1(0.8 \%)$ & $1(0.4 \%)$ \\
\hline 1st degree & $7(5.9 \%)$ & $10(8.1 \%)$ & $17(7 \%)$ \\
\hline 2nd degree & $34(28.6 \%)$ & $38(30.6 \%)$ & $72(29.6 \%)$ \\
\hline 3a OASI & $1(0.8 \%)$ & $1(0.8 \%)$ & $2(0.8 \%)$ \\
\hline 3b OASI & $1(0.8 \%)$ & $0(0 \%)$ & $1(0.4 \%)$ \\
\hline Unspecified OASI & $1(0.8 \%)$ & $0(0 \%)$ & $1(0.4 \%)$ \\
\hline Intact perineum & $31(26.1 \%)$ & $28(22.6 \%)$ & $59(24.3 \%)$ \\
\hline Not Applicable & $19(16 \%)$ & $18(14.5 \%)$ & $37(15.2 \%)$ \\
\hline Missing & 25 (21\%) & 28 (22.6\%) & $53(21.8 \%)$ \\
\hline Episiotomy & & & \\
\hline
\end{tabular}




\begin{tabular}{|llll|}
\hline Yes & $16(13.4 \%)$ & $16(12.9 \%)$ & $32(13.2 \%)$ \\
\hline Missing & $76(63.9 \%)$ & $80(64.5 \%)$ & $156(64.2 \%)$ \\
\hline Birth Weight [n] & $27(22.7 \%)$ & $28(22.6 \%)$ & $55(22.6 \%)$ \\
\hline Mean (SD) & {$[\mathrm{n}=97]$} & {$[\mathrm{n}=100]$} & {$[\mathrm{n}=197]$} \\
\hline Missing & $3232(457)$ & $3348(482)$ & $3291(472)$ \\
\hline Head Circumference [n] & $22(18 \%)$ & $24(19 \%)$ & $46(19 \%)$ \\
\hline Mean (SD) & {$[\mathrm{n}=90]$} & {$[\mathrm{n}=95]$} & {$[\mathrm{n}=185]$} \\
\hline Missing & $34(1.44)$ & $34(1.40)$ & $34.1(1.42)$ \\
\hline Length of Active 2nd Stage (in minutes) [n] & {$[\mathrm{n}=53]$} & {$[\mathrm{n}=50]$} & {$[\mathrm{n}=103]$} \\
\hline Median [IQR] & $15(7,53)$ & $19(5,42)$ & $19(6,49)$ \\
\hline Missing & $66(55 \%)$ & $74(60 \%)$ & $140(58 \%)$ \\
\hline
\end{tabular}

The prevalence of $\mathrm{UI}$ and bowel incontinence were secondary outcomes. Of total responders, $49 \%$ $(119 / 243)$ reported some degree of leaking of urine in the four week period prior to questionnaire completion and this was similar between trial arms (Table 2). Bowel incontinence rates are summarised in Table 3.

Table 2: Results of ICIQ-UI SF Questionnaire for urinary incontinence 


\begin{tabular}{|c|c|c|c|}
\hline Outcome & $\begin{array}{l}\text { Long } \\
(\mathrm{N}=119)\end{array}$ & $\begin{array}{l}\text { Short part } \\
A \\
(N=124)\end{array}$ & $\begin{array}{l}\text { Total } \\
(\mathrm{N}=243)\end{array}$ \\
\hline Urinary Incontinence & $\begin{array}{l}59 \\
(49.5 \%)\end{array}$ & $\begin{array}{l}59 \\
(48.4 \%)\end{array}$ & $119(49 \%)$ \\
\hline Presence & & & $124(51 \%)$ \\
\hline Absence & $(50.4 \%)$ & $\begin{array}{l}64 \\
(51.6 \%)\end{array}$ & $1(0.4 \%)$ \\
\hline Missing & $0(0 \%)$ & $1(0.8 \%)$ & \\
\hline \multicolumn{4}{|l|}{ Bladder function questions } \\
\hline \multicolumn{4}{|l|}{ How often do you leak urine? } \\
\hline Never & $\begin{array}{l}65 \\
(54.6 \%)\end{array}$ & $\begin{array}{l}69 \\
(55.6 \%)\end{array}$ & $\begin{array}{l}134 \\
(55.1 \%)\end{array}$ \\
\hline About once a week or less often & $\begin{array}{l}30 \\
(25.2 \%)\end{array}$ & $\begin{array}{l}33 \\
(26.6 \%)\end{array}$ & $\begin{array}{l}63 \\
(25.9 \%)\end{array}$ \\
\hline Two or three times a day & $\begin{array}{l}12 \\
(10.1 \%)\end{array}$ & $8(6.5 \%)$ & $20(8.2 \%)$ \\
\hline About once a day & $5(4.2 \%)$ & $4(3.2 \%)$ & $9(3.7 \%)$ \\
\hline Several times a day & $6(5 \%)$ & $7(5.6 \%)$ & $13(5.3 \%)$ \\
\hline All of the time & $0(0 \%)$ & $1(0.8 \%)$ & $1(0.4 \%)$ \\
\hline Missing & $1(0.8 \%)$ & $2(1.6 \%)$ & $3(1.2 \%)$ \\
\hline \multicolumn{4}{|c|}{ How much urine do you usually leak? } \\
\hline None & $\begin{array}{l}64 \\
(53.8 \%)\end{array}$ & $\begin{array}{l}63 \\
(50.8 \%)\end{array}$ & $\begin{array}{l}127 \\
(52.3 \%)\end{array}$ \\
\hline A small amount & $\begin{array}{l}47 \\
(39.5 \%)\end{array}$ & $\begin{array}{l}46 \\
(37.1 \%)\end{array}$ & $\begin{array}{l}93 \\
(38.3 \%)\end{array}$ \\
\hline A moderate amount & $6(5 \%)$ & $8(6.5 \%)$ & $14(5.8 \%)$ \\
\hline A large amount & $0(0 \%)$ & $0(0 \%)$ & $0(0 \%)$ \\
\hline Missing & $2(1.7 \%)$ & $7(5.6 \%)$ & $9(3.7 \%)$ \\
\hline \multicolumn{4}{|c|}{$\begin{array}{l}\text { Overall, how much does leaking urine interfere with your } \\
\text { everyday life? }\end{array}$} \\
\hline (not at all) 0 & $\begin{array}{l}72 \\
(60.5 \%)\end{array}$ & $\begin{array}{l}73 \\
(58.9 \%)\end{array}$ & $\begin{array}{l}145 \\
(59.7 \%)\end{array}$ \\
\hline 1 & $\begin{array}{l}14 \\
(11.8 \%)\end{array}$ & $\begin{array}{l}20 \\
(16.1 \%)\end{array}$ & $34(14 \%)$ \\
\hline 2 & $9(7.6 \%)$ & 8 (6.5\%) & $17(7 \%)$ \\
\hline
\end{tabular}




\begin{tabular}{|llll|}
\hline 3 & $7(5.9 \%)$ & $8(6.5 \%)$ & $15(6.2 \%)$ \\
\hline 4 & $5(4.2 \%)$ & $2(1.6 \%)$ & $7(2.9 \%)$ \\
\hline 6 & $1(0.8 \%)$ & $3(2.4 \%)$ & $4(1.6 \%)$ \\
\hline 7 & $2(1.7 \%)$ & $3(2.4 \%)$ & $5(2.1 \%)$ \\
\hline 8 & $3(2.5 \%)$ & $2(1.6 \%)$ & $5(2.1 \%)$ \\
\hline 9 & $2(1.7 \%)$ & $0(0 \%)$ & $2(0.8 \%)$ \\
\hline a great deal) 10 & $1(0.8 \%)$ & $1(0.8 \%)$ & $2(0.8 \%)$ \\
\hline Missing & $0(0 \%)$ & $2(1.6 \%)$ & $2(0.8 \%)$ \\
\hline When does urine leak? & $3(2.5 \%)$ & $2(1.6 \%)$ & $5(2.1 \%)$ \\
\hline Never & & & \\
\hline Before you can get to the toilet & 60 & 68 & 128 \\
\hline When you sneeze & $(50.4 \%)$ & $(54.8 \%)$ & $(52.7 \%)$ \\
\hline When you are asleep & 22 & 19 & 41 \\
\hline When you are physically active/exercising & $(18.5 \%)$ & $(15.3 \%)$ & $(16.9 \%)$ \\
\hline When you have finished urinating and are getting dressed & $7(5.9 \%)$ & $7(5.6 \%)$ & $14(5.8 \%)$ \\
\hline For no obvious reason & $6(5 \%)$ & $4(3.2 \%)$ & $10(4.1 \%)$ \\
\hline All of the time & $(33.6 \%)$ & $31(25 \%)$ & 71 \\
\hline & $3(2.5 \%)$ & $1(0.8 \%)$ & $4(1.6 \%)$ \\
\hline
\end{tabular}

Table 3: Results of RFIS Questionnaire for bowel incontinence 


\begin{tabular}{|c|c|c|c|}
\hline Outcome & $\begin{array}{l}\text { Long } \\
(\mathrm{N}=119)\end{array}$ & $\begin{array}{l}\text { Short part } \\
A \\
(N=124)\end{array}$ & $\begin{array}{l}\text { Total } \\
(\mathrm{N}=243)\end{array}$ \\
\hline Bowel Incontinence & $31(26 \%)$ & $19(15.3 \%)$ & $50(20.6 \%)$ \\
\hline Presence & $88(74 \%)$ & \multirow{2}{*}{$\begin{array}{l}104 \\
(83.9 \%)\end{array}$} & $192(79 \%)$ \\
\hline Absence & \multirow[t]{2}{*}{$0(0 \%)$} & & \multirow[t]{2}{*}{$1(0.4 \%)$} \\
\hline Missing & & ) & \\
\hline \multicolumn{4}{|c|}{ Bowel Function Questions } \\
\hline \multicolumn{4}{|c|}{$\begin{array}{l}\text { Do you leak, have accidents or lose control with solid } \\
\text { stool? }\end{array}$} \\
\hline Never & $\begin{array}{l}101 \\
(84.9 \%)\end{array}$ & $\begin{array}{l}117 \\
(94.4 \%)\end{array}$ & $\begin{array}{l}218 \\
(89.7 \%)\end{array}$ \\
\hline Rarely & $9(7.6 \%)$ & $5(4 \%)$ & $14(5.8 \%)$ \\
\hline Sometimes & $6(5 \%)$ & $0(0 \%)$ & $6(2.5 \%)$ \\
\hline Often or usually & $2(1.7 \%)$ & $1(0.8 \%)$ & $3(1.2 \%)$ \\
\hline Always & $1(0.8 \%)$ & $0(0 \%)$ & $1(0.4 \%)$ \\
\hline Missing & $0(0 \%)$ & $1(0.8 \%)$ & $1(0.4 \%)$ \\
\hline \multicolumn{4}{|c|}{$\begin{array}{l}\text { Do you leak, have accidents or lose control with liquid } \\
\text { stool? }\end{array}$} \\
\hline Never & $100(84 \%)$ & $\begin{array}{l}110 \\
(88.7 \%)\end{array}$ & $\begin{array}{l}210 \\
(86.4 \%)\end{array}$ \\
\hline Rarely & $11(9.2 \%)$ & $10(8.1 \%)$ & $21(8.6 \%)$ \\
\hline Sometimes & $5(4.2 \%)$ & $1(0.8 \%)$ & $6(2.5 \%)$ \\
\hline Often or usually & $2(1.7 \%)$ & $2(1.6 \%)$ & $4(1.6 \%)$ \\
\hline Always & $1(0.8 \%)$ & $0(0 \%)$ & $1(0.4 \%)$ \\
\hline Missing & $0(0 \%)$ & $1(0.8 \%)$ & $1(0.4 \%)$ \\
\hline \multicolumn{4}{|c|}{ Do you leak stool if you don't get to the toilet in time? } \\
\hline Never & $99(83.2 \%)$ & $\begin{array}{l}114 \\
(91.9 \%)\end{array}$ & $\begin{array}{l}213 \\
(87.7 \%)\end{array}$ \\
\hline Rarely & $10(8.4 \%)$ & $6(4.8 \%)$ & $16(6.6 \%)$ \\
\hline Sometimes & $9(7.6 \%)$ & $1(0.8 \%)$ & $10(4.1 \%)$ \\
\hline Often or usually & $0(0 \%)$ & $0(0 \%)$ & $0(0 \%)$ \\
\hline
\end{tabular}




\begin{tabular}{|llll|}
\hline Always & $1(0.8 \%)$ & $2(1.6 \%)$ & $3(1.2 \%)$ \\
\hline Missing & $0(0 \%)$ & $1(0.8 \%)$ & $1(0.4 \%)$ \\
\hline $\begin{array}{l}\text { Does stool leak so that you have to change your } \\
\text { underwear? }\end{array}$ & & & \\
\hline Never & $100(84 \%)$ & 114 & 214 \\
\hline Rarely & $11(9.2 \%)$ & $5(4 \%)$ & $16(6.6 \%)$ \\
\hline Sometimes & $6(5 \%)$ & $2(1.6 \%)$ & $8(3.3 \%)$ \\
\hline Often or usually & $1(0.8 \%)$ & $1(0.8 \%)$ & $2(0.8 \%)$ \\
\hline Always & $1(0.8 \%)$ & $1(0.8 \%)$ & $2(0.8 \%)$ \\
\hline Missing & $0(0 \%)$ & $1(0.8 \%)$ & $1(0.4 \%)$ \\
\hline $\begin{array}{l}\text { Does bowel or stool leakage cause you to alter your } \\
\text { lifestyle? }\end{array}$ & & & \\
\hline Never & 107 & 116 & 223 \\
\hline Rarely & $(89.9 \%)$ & $(93.5 \%)$ & $(91.8 \%)$ \\
\hline Sometimes & $6(5 \%)$ & $2(1.6 \%)$ & $8(3.3 \%)$ \\
\hline Often or usually & $3(2.5 \%)$ & $2(1.6 \%)$ & $5(2.1 \%)$ \\
\hline Always & $2(1.7 \%)$ & $1(0.8 \%)$ & $3(1.2 \%)$ \\
\hline Missing & $1(0.8 \%)$ & $1(0.8 \%)$ & $2(0.8 \%)$ \\
\hline
\end{tabular}

A total of $64.2 \%$ (156/243) women reported that they had been advised to perform PFME during their pregnancy by a midwife and this was similar between trial arms. Most women, both during pregnancy and in the last postpartum month, reported doing these less often than once a day (Table 4).

Table 4: Results of performance of PFME during the pregnancy 


\begin{tabular}{|c|c|c|c|}
\hline Outcome & $\begin{array}{l}\text { Long } \\
(\mathrm{N}=119)\end{array}$ & $\begin{array}{l}\text { Short } \\
\text { Part A } \\
(\mathrm{N}=124)\end{array}$ & $\begin{array}{l}\text { Total } \\
(\mathrm{N}=243)\end{array}$ \\
\hline $\begin{array}{l}\text { Did your midwife advise you to perform Pelvic Floor Muscle } \\
\text { Exercises when you were pregnant? }\end{array}$ & $\begin{array}{l}77 \\
(64.6 \%)\end{array}$ & $\begin{array}{l}79 \\
(63.7 \%)\end{array}$ & $\begin{array}{l}156 \\
(64.2 \%)\end{array}$ \\
\hline \multirow{2}{*}{$\begin{array}{l}\text { Yes } \\
\text { No } \\
\text { Missing }\end{array}$} & $\begin{array}{l}21 \\
(17.7 \%)\end{array}$ & 22 & $\begin{array}{l}43 \\
(17.7 \%)\end{array}$ \\
\hline & $\begin{array}{l}21 \\
(17.7 \%)\end{array}$ & $\begin{array}{l}23 \\
(18.6 \%)\end{array}$ & $\begin{array}{l}44 \\
(18.1 \%)\end{array}$ \\
\hline $\begin{array}{l}\text { How often did you perform Pelvic Floor Muscle Exercises when } \\
\text { you were pregnant? }\end{array}$ & $\begin{array}{l}17 \\
(14.3 \%)\end{array}$ & $\begin{array}{l}22 \\
(17.7 \%)\end{array}$ & $\begin{array}{l}39 \\
(16.0 \%)\end{array}$ \\
\hline \multirow{10}{*}{$\begin{array}{l}\text { Never - was never advised to } \\
\text { Never - other reasons } \\
\text { A few times a month } \\
\text { A few times a week } \\
\text { Once a week } \\
\text { Once a day } \\
\text { A few times a day } \\
\text { Can't remember } \\
\text { Missing }\end{array}$} & $9(7.6 \%)$ & $\begin{array}{l}12 \\
(9.7 \%)\end{array}$ & $\begin{array}{l}21 \\
(8.6 \%)\end{array}$ \\
\hline & $\begin{array}{l}38 \\
(31.9 \%)\end{array}$ & & \\
\hline & & $(17.7 \%)$ & $(24.7 \%)$ \\
\hline & $(20.2 \%)$ & $\begin{array}{l}29 \\
(23.4 \%)\end{array}$ & $\begin{array}{l}53 \\
(218 \%)\end{array}$ \\
\hline & $4(3.4 \%)$ & $4(3.2 \%)$ & $8(3,3 \%)$ \\
\hline & $\begin{array}{l}10 \\
(8.4 \%)\end{array}$ & 12 & 22 \\
\hline & $\begin{array}{l}13 \\
(10.9 \%)\end{array}$ & 15 & \\
\hline & $3(2.5 \%)$ & & \\
\hline & $1(0.8 \%)$ & $0(0.0 \%)$ & $(4.5 \%)$ \\
\hline & & (4) & $1(0.4 \%)$ \\
\hline Do you currently perform Pelvic Floor Muscle Exercises & $\begin{array}{l}73 \\
(61.3 \%)\end{array}$ & $\begin{array}{l}73 \\
(58.8 \%)\end{array}$ & $\begin{array}{l}146 \\
(60.1 \%)\end{array}$ \\
\hline No & $\begin{array}{l}36 \\
(30.3 \%)\end{array}$ & $\begin{array}{l}38 \\
(30.7 \%)\end{array}$ & $\begin{array}{l}74 \\
(30.4 \%)\end{array}$ \\
\hline Missing & $\begin{array}{l}10 \\
(8.4 \%)\end{array}$ & $\begin{array}{l}13 \\
(10.5 \%)\end{array}$ & $\begin{array}{l}23 \\
(9.5 \%)\end{array}$ \\
\hline $\begin{array}{l}\text { How often did you do Pelvic Floor Muscle Exercises over the last } \\
\text { month? }\end{array}$ & $\begin{array}{l}10 \\
(8.4 \%)\end{array}$ & $\begin{array}{l}13 \\
(10.5 \%)\end{array}$ & $\begin{array}{l}23 \\
(9.5 \%)\end{array}$ \\
\hline Never - was never advised to & $\begin{array}{l}15 \\
(12.6 \%)\end{array}$ & $\begin{array}{l}18 \\
(14.5 \%)\end{array}$ & $\begin{array}{l}33 \\
(13.6 \%)\end{array}$ \\
\hline A few times a month & $\begin{array}{l}41 \\
(34.5 \%)\end{array}$ & $\begin{array}{l}33 \\
(26.6 \%)\end{array}$ & $\begin{array}{l}74 \\
(30.5 \%)\end{array}$ \\
\hline A few times a week & $\begin{array}{l}25 \\
(21.0 \%)\end{array}$ & $\begin{array}{l}22 \\
(17.7 \%)\end{array}$ & $\begin{array}{l}47 \\
(19.3 \%)\end{array}$ \\
\hline
\end{tabular}


Once a day

\section{1}

A few times a day

14

12

Missing

(10.1\%)

15

$0(0 \%)$

(12.1\%)

$1(0.8 \%)$

\section{Discussion}

This well designed randomised controlled trial found very similar rates for both the final overall response rate and the response rate for the urinary incontinence questions from either the long or short questionnaire. This is contrary to the findings from the Cochrane review meta-analysis of studies comparing final response rates for shorter versus longer questionnaires that showed an improved return from a shorter questionnaire (OR 1.64, 95\% $\mathrm{Cl} 1.43-1.87$ ). One possible explanation is that the questionnaires in this study were both relatively short. In the Cochrane meta-analysis, 55 studies reported questionnaire length and these ranged from two questions and 28 pages for the short questionnaire and five questions and 36 pages for the long questionnaire. The period of response for the studies in the meta-analysis was not specified in most (48/55) and there was a wide range of questionnaire topics. Of the 29 studies that were 'health' related, two asked questions on bowel and/or bladder function $(16,17)$ and both demonstrated higher response rate from the shorter questionnaire: Kalantar et al (1999) showed an OR 1.46 [95\% Cl 0.97-2.22] and Koloski et al (2001) OR 1.34 [0.90-2.00]. However, this may be accounted for by differences in both the lengths of the shorter questionnaire (one page and 28 pages respectively) and their longer comparators (seven pages and 32 pages respectively) in both of these previous trials compared to the present trial.

The overall response for this study was low at $31.3 \%$ and $30.9 \%$ for presence or absence of Ul. This was despite the study incorporating recommendations from the Cochrane review of methods to increase responses to postal and electronic questionnaires (6), namely; first class postage for outward mailing; first class stamped envelopes for return mailing; a $£ 10$ voucher sent with the initial mailing as a financial incentive and sending a reminder questionnaire on non-return after a two week period. Within a similar topic area, a set of UK National Maternity Surveys from 1995 onwards, which have used postal questionnaires to survey women at about 3 months postpartum, have shown a decline from a $67 \%$ response in 1995 to $47 \%$ in 2014. The UK Infant Feeding Surveys and the Care Quality Commission Maternity Surveys have also showed similar declines in response rate $(4,18)$. The group undertaking the UK National Maternity Surveys recently tested a range of methods to increase their response rate in two pilots before undertaking the latest survey. The first pilot used the same methods as the earlier surveys and got a response from women of $28.7 \%$. The second pilot that used several new methods to increase response did achieve this, but only up to $33.1 \%$. One of the methods was to shorten the questionnaire from 20 to 16 pages, but as in our study, this was not found to have any effect on the response rate (19). 
The prevalence of any degree of urinary incontinence in the total responders was $49 \%$ (119/243) which is in keeping with others studies $(20,21)$. Any type of bowel incontinence was reported by $20.5 \%(50 / 243)$ women within the four weeks prior to completing the questionnaire. This rate is similar to that from previous studies that have looked at bowel symptoms within the first three months following childbirth $(22,23)$.

The main strength of this study is that it was a high quality randomised controlled trial using appropriate randomisation to questionnaire type, full description of the sample and methodology that other studies within the Cochrane review are lacking (6). A further strength of this study is that the baseline characteristics of women who returned both types of questionnaire are comparable; therefore any suggestion of bias between groups can be eliminated. The main weakness was the overall low response but it is unlikely that this would have resulted in major bias given that the characteristics of both groups were similar.

\section{Conclusion}

There is limited evidence of methods to improve postal questionnaire response rates for health studies in general or for maternity in particular. This study has used high quality trial methods and shown that response rates both overall and to the urinary incontinence questions were comparable from either a long or short questionnaire, although both questionnaires were relatively short compared with the length of questionnaires used in some studies.

\section{Abbreviations}

APPEAL Antenatal Preventative Pelvic Floor Exercises and Localisation study

BCTU Birmingham Clinical Trials Unit

ICIQ-UI SF International Consultation on Incontinence Questionnaire - Urinary Incontinence Short Form

PFME Pelvic Floor Muscle Exercises

PFMSES Pelvic Floor Muscle Self Efficacy Scale

RFIS Revised Faecal Incontinence Scale

SF-12 12 item - Short Form Survey

UI Urinary Incontinence

\section{Declarations}

\section{Ethics approval and consent to participate}


Ethical approval for the study was obtained from the Proportionate Review Sub-committee of the London - Brighton \& Sussex Research Ethics Committee (18/LO/0934). Consent to participate in the study, as per study protocol, was obtained by the women returning the questionnaire. It was made clear in the cover letter accompanying the questionnaire that return of the questionnaire was consent for their questionnaire answers to be used in the study however there were additional tick boxes for the women to provide consent to access maternity hospital records, request for study results and agreement to be contacted in the future in case of for further research.

\section{Consent for publication}

Not applicable

\section{Availability of data and materials}

Ethics submission, letters to participants and ethics approval are available from the first author. The only submitted additional files are the Consort 2010 Checklist and the two versions of questionnaires posted to the women. The datasets used and/or analysed during the current study are available from the corresponding author on reasonable request.

\section{Competing interests}

There are no competing interests by any of the authors.

\section{Funding}

All of the work in this study (salaries, consumables, expenses) was funded by NIHR Programme Grant for Applied Research (RP-PG-0514-20002).

\section{Transparency Declaration}

This manuscript is a transparent account of the study. No important aspects of the study have been omitted.

\section{Authors' Contributions}

$\mathrm{CM}$ is Chief Investigator for the APPEAL Study NIHR Programme Grant. SW was Chief Investigator for this methodology trial. SW drafted the paper with critical revisions from CM, EJ and JB. EJ is research midwife on the study and JB is trial statistician. All authors have read and approved the manuscript.

\section{Acknowledgements}

None

\section{Authors' information}




\section{Funding}

NIHR Programme Grant for Applied Research RP-PG-0514-20002

\section{References}

1. Armstrong B, White E, Saracci R. Principles of exposure measurement in epidemiology. In: Kelsey J, Marmot M, Stolley P, Vessey M, editors. Monographs in Epidemiology and Biostatistics. First edition. New York: Oxford University Press Inc.; 1995. p. 294-321.

2. Council NR. Nonresponse in Social Science Surveys: A Research Agenda. . Washington DC: The National Academies Press; 2013. Available from: https://doi.org/10.17226/18293.

3. Galea S, Tracy M. Participation in epidemiologic studies. Annnals of Epidemiology. 2007;17:643-53.

4. McAndrew F, Thompson J, Fellows L, Large A, Speed M, Renfrew M. Infant Feeding Survey 2010. Health and social care information Centre. 2012.

5. Care Quality Commission. Maternity Services Survey 2010. 2010, http://www.cqc.org.uk/maternitysurvey2010.cfm.

6. Edwards P, Roberts I, Clarke M, DiGuiseppi C, Wentz R, Kwan I, et al. Methods to increase response to postal and electronic questionnaires. Cochrane Database of Systematic Reviews. 2009(Issue 3).

7. Singer E, Ye C. The use and effects of incentives in surveys. Annals of American Academy of Political and Social Science. 2013;645(1):112-41.

8. Robb K, Getting L, Wardle J. What impact do questionnaire length and monetary incentives have on mailed health psychology survey response? British Journal of Health Psychology. 2017;22(4):671-85.

9. Brueton V, Tierney J, Stenning S, Meredith S, Harding S, Nazareth I, et al. Strategies to improve retention in randomisation trials: a Cochrane systematic review and meta-analysis. BMJ Open. 2014;4e003821.

10. Hammink A, Giesen P, Wenseng M. Pre-notification did not increase response rate in addition to follow-up: a randomised trial. J Clin Epidemiol. 2010;63(11):1276-8.

11. Carey R, Reid A, Driscoll T, Glass D, Benke G, Frischi L. An advanced letter did not increase the response rates in a telephone survey: a randomised trial. J Clin Epidemiol. 2013;66(12):1417-21.

12. Avery K, Donovan J, Peters T, Shaw C, Gotoh M, Abrams P. ICIQ: a brief and robust measure for evaluating the symptoms and impact of urinary incontinence. neurourology and Urodynamics. 2004;23(4):322-30.

13. Sansoni J, Hawthorne G, Marosszeky N, Moore K, Fleming G, Owen E. Validation and Clinical Translation of the Revised Continence and Patient Satisfaction Tools: Final Report. . Centre for Health Service Development, University of Wollongong., 2011.

14. Chen S-Y. Pelvic Floor Muscle Exercise Self-Efficacy Scale. Journal of Nursing Research. 2004;12(4):257-65 
15. Ware JJ, Kosinski M, Keller S. A 12-Item Short-Form Health Survey: construction of scales and preliminary tests of reliability and validity. Journal of Medical Care. 1996;34(3):220-33.

16. Kalantar J, Talley N. The effects of lottery incentive and length of questionnaire on health survey response rates: a randomised study. Journal of Clinical Epidemiology. 1999;52(11):1117-22.

17. Koloski N, Talley N, Boyce P, Morris-Yates A. The effects of questionnaire length and lottery ticket inducement on the response rate in mail surveys. Psychology and Health. 2001;16:67-75.

18. Commission CQ. National findings from the 2018 survey of women's experiences of maternity care. London: CQC, 2018.

19. Harrison S, Henderson J, Alderdice F, Quigley A. Methods to increase response rates to a populationbased maternity survey: a comparison of two pilot studies. BMC Medical Research Methodology. 2019:19-65.

20. Wesnes S, Hunskaar S, Bo K, Rortveit G. The effect of urinary incontinence status during pregnancy and delivery mode on incontinence postpartum. A cohort study. BJOG. 2009;116(5):700-7.

21. Gartland D, Donath S, MacArthur C, Brown S. Urinary incontinence in nulliparous women: Pregnancy, birth and the first 18 months postpartum. Journal of Paediatrics and Child Health. 2012;48.

22. Guise J, Morris C, Osterweil P, Li H, Rosenberg D, Greenlick M. Incidence of fecal incontinence after childbirth. Obstet Gynecol. 2007;109((2 Part 1)):281-8.

23. MacArthur C, Glazener CMA, Wilson PD, Herbison GP, Gee H, Lang GD, et al. Obstetric practice and faecal incontinence three months after delivery. British Journal of Obstetrics and Gynaecology. 2001;108(7):678-83.

\section{Figures}




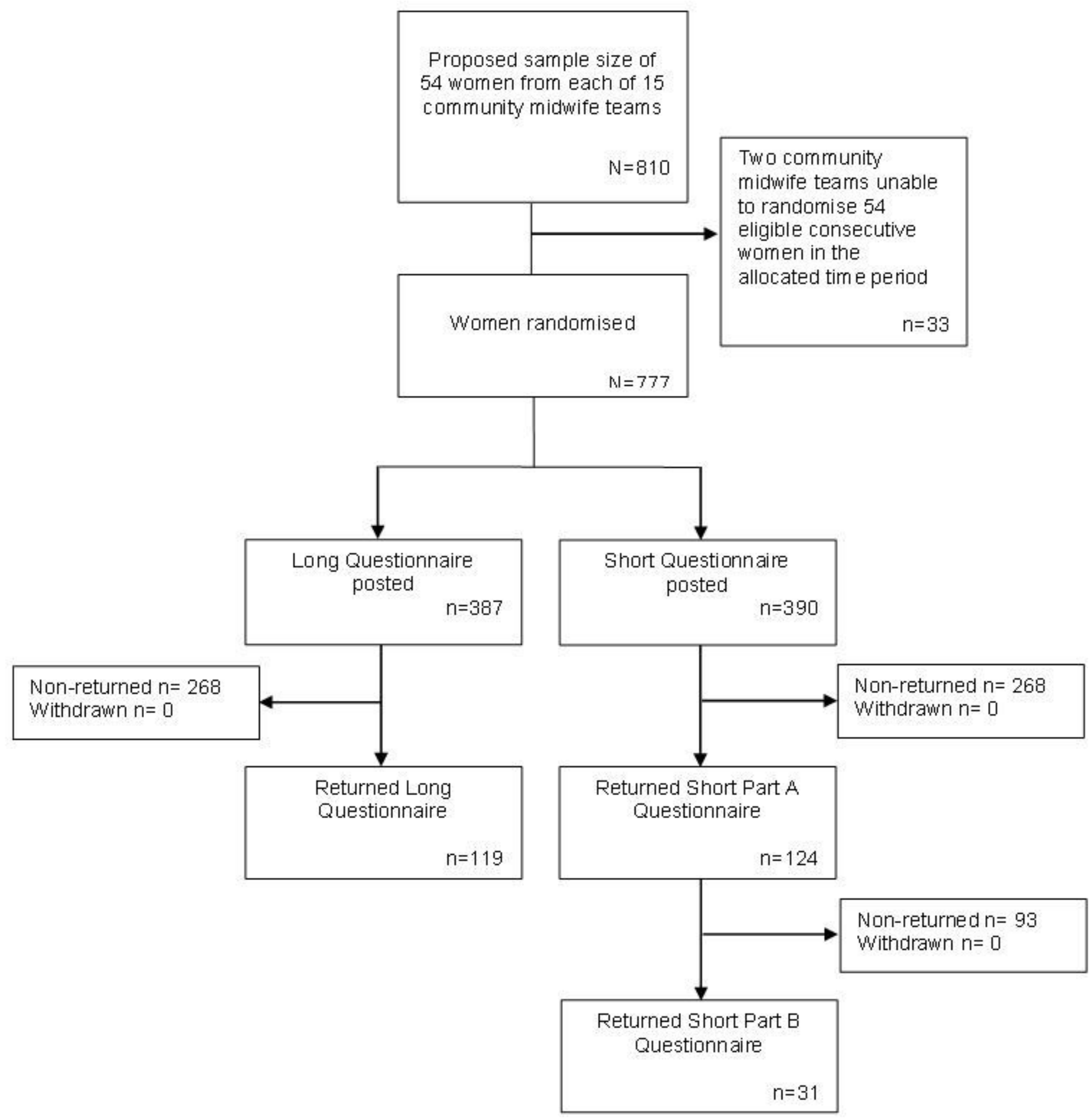

Figure 1

CONSORT flow diagram

\section{Supplementary Files}

This is a list of supplementary files associated with this preprint. Click to download.

- Additionalfile1.doc 
- Additionalfile4.pdf

- Additionalfile3.pdf

- Additionalfile2.pdf 